\title{
Phytoseiid mites (Acari: Phytoseiidae) from Sumatra with description of a new species
}

\author{
Shôzô Ehara
}

Hamasaka 2-15-7, Tottori, 680-0001 Japan

\begin{abstract}
Twelve species of the mite family Phytoseiidae are reported from West Sumatra, Indonesia. Amblyseius (Amblyseius) sumatrensis sp. nov. is described and illustrated. Eleven named species are recorded for the first time in Sumatra. The male of Amblyseius (Neoseiulus) circellatus Wu \& Li 1983, previously unknown, is described.

Key words - Acari, fauna, Indonesia, new species, Phytoseiidae, Sumatra
\end{abstract}

Mites of the family Phytoseiidae are ranked among the effective biological control agents for phytophagous mites on agricultural crops in many parts of the world. There is very little information about phytoseiid mites from Sumatra, Indonesia. Prior to the present work, Typhlodromus heveae Oudemans 1930 and T. hevearum Oudemans 1930 were described from Medan, N. Sumatra on Hevea sp. Oomen (1982) found that Amblyseius largoensis (Muma 1955) was in association with the scarlet mite Brevipalpus phoenicis (Geijskes 1939) on tea plants in Sumatra and Java.

This paper reports 12 species of phytoseiids, one of which is described as new and 11 are first recorded from Sumatra. The collections on which this study is based were made by Dr. Akio Takafuji, Kyoto University, during December of 1981 in West Sumatra.

The setal nomenclature follows that of Rowell et al. (1978). The generic and subgeneric concepts adopted in this paper generally follows those of Ehara \& Amano (1998). All the measurements are given in micrometers, and those of the holotype of the new species are in parentheses following the mean. The holotype and part of the paratypes of the new species are deposited in the collection of the National Science Museum, Tokyo; the remainder of the paratypes will be retained in the Museum Zoologicum Bogoriense, Bogor, Indonesia.

\section{Amblyseius (Neoseiulus) longispinosus (Evans 1952)}

Typhlodromus longispinosus Evans 1952, p. 413, figs. 1, 2 (type locality: Bogor, Java, Indonesia; type habitat: Manihot utilissima Pohl).

Typhlodromus (Amblyseius) longispinosus: Chant 1959, p. 74, figs. 114, 115.

Amblyseius (Amblyseius) longispinosus: Ehara 1966, p. 21 (in part).

Cydnodromus longispinosus: Muma 1967, p. 267.

Amblyseius longispinosus: Schicha 1975, p. 103, figs. 10-17.

Neoseiulus longispinosus: Gupta 1978, p. 334; Beard 2001, p. 85 , fig. 6e-g.
Amblyseius (Neoseiulus) longispinosus: Ehara 2002, p. 29, fig. 1 .

The female of this species closely resembles that of $A$. (N.) womersleyi Schicha 1975 but differs in having seta S5 about one third as long as $\mathrm{S} 4$, as opposed to slightly shorter than S4 in womersleyi.

Specimens examined. Padang: 1 우 \& 10, 9-XII-1981, on cassava.

Distribution. China, Taiwan, Thailand, Malaysia, the Philippines, Hawaii, Indonesia (Java; Sumatra, new record), India, Pakistan, Papua New Guinea, Australia, New Zealand.

\section{Amblyseius (Neoseiulus) circellatus Wu \& Li 1983}

(Figs. 1-9)

Amblyseius (Amblyseius) circellatus Wu \& Li 1983, p. 173, figs. 13-17 (type loc.: Jianyang Xian, Dazhulan, Fujian Province, China; type habitat: Machilus thunbergii Sieb. \& Zucc.). Amblyseius circellatus: Wu et al. 1997, p. 77, fig. 47.

Female. Body slender; dorsal shield reticulate on anterolateral area, with at least 6 pairs of solenostomes (Fig. 1). Setae on dorsal shield: $Z 5$ the longest, stout, barbed; remaining setae much shorter, smooth. Setae $r 3$ longer than R1, both setae smooth. Peritreme extending forward to level between z2 and z4 (between coxae II and III); posterior extension of peritrematal shield not observable. Sternal shield ill-defined, with 3 pairs of setae; metasternal platelets slender (Fig. 2). Ventrianal shield much longer than wide, much narrower than genital shield, with lateral margins concave; 3 pairs of preanal setae and pair of large crescentic solenostomes (Fig. 3). Two pairs of very slender metapodal platelets. Spermathecal cervix fundibular; the atrium saccular with thick, heavily sclerotized walls (Figs. 4, 5). Fixed digit of chelicera with 5 teeth, movable digit unidentate (Fig. 6). Chaetotaxic formula: genu II, 2-2/0, 2/01; genu III, 1-2/1, 2/0-1. Genua I-III without macrosetae. 


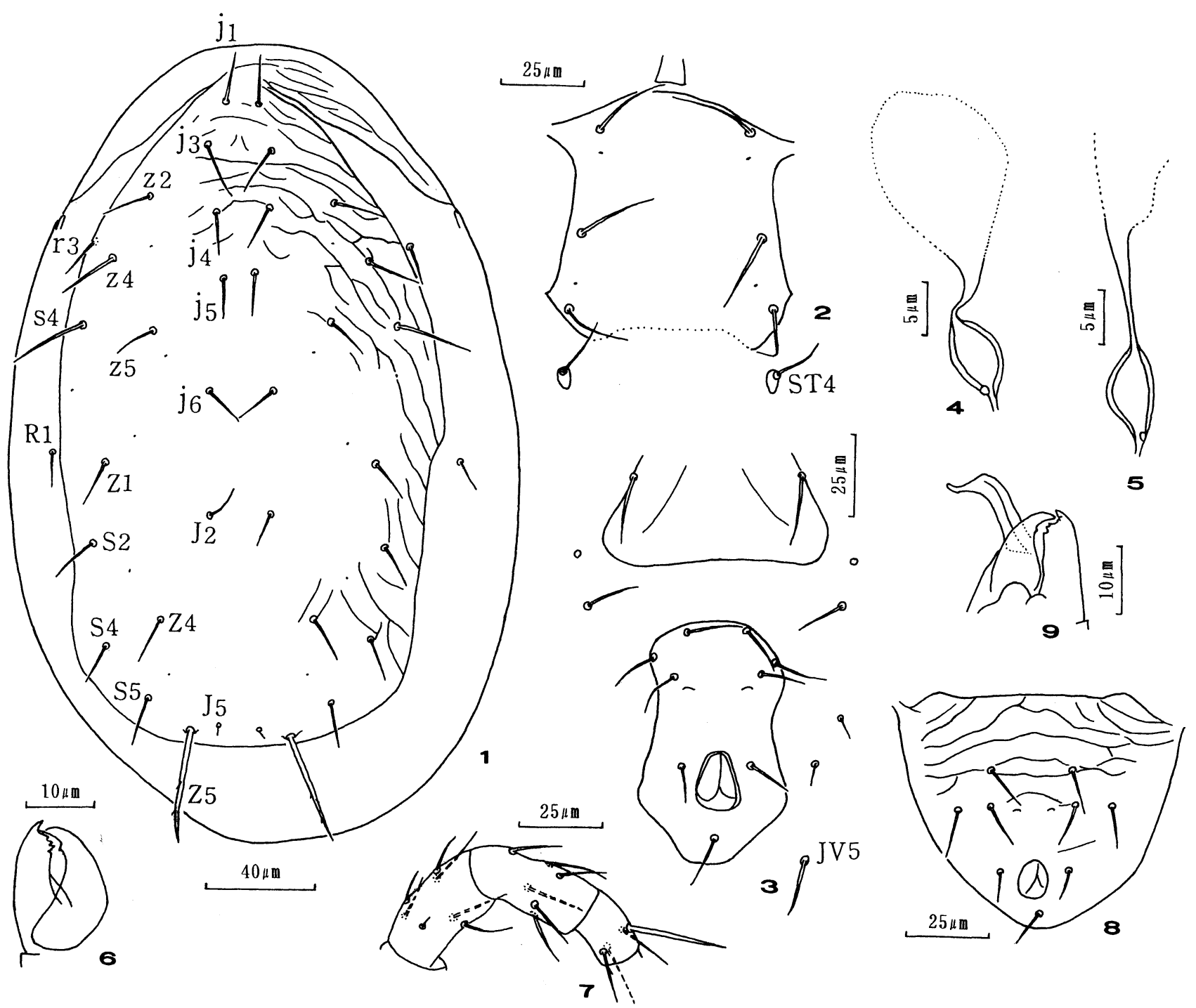

Figs. 1-9. Amblyseius (Neoseiulus) circellatus. - 1, dorsum of idiosoma (gravid ㅇ); 2, sternal shield (早); 3, posterior ventral

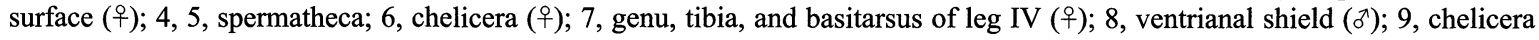
(ठ).

Leg IV with 1 attenuate macroseta on genu (Fig. 7). Measurements: length of idiosoma 291, width of idiosoma 135 (183 in a gravid + +); lengths of setae (mean $\pm \mathrm{SE}, \mathrm{n}=10$ ): j1 $18.2 \pm 0.3, \mathrm{j} 320.6 \pm 0.2, \mathrm{j} 416.5 \pm 0.3, \mathrm{j} 515.6 \pm 0.2, \mathrm{j} 6$ $16.2 \pm 0.2, \mathrm{~J} 215.9 \pm 0.5, \mathrm{~J} 55.4 \pm 0.1, \mathrm{z} 221.7 \pm 0.3, \mathrm{z} 422.6$ \pm 0.3 , z5 $15.7 \pm 0.3, \mathrm{Z} 1 \quad 16.6 \pm 0.3, \mathrm{Z} 417.1 \pm 0.2$, Z5 38.4 \pm 0.3 , s4 29.1 \pm 0.3 , S2 $19.4 \pm 0.2$, S4 $16.9 \pm 0.3$, S5 18.8 $\pm 0.3, \mathrm{r} 322.4 \pm 0.2, \mathrm{R} 1 \quad 14.2 \pm 0.3$, JV5 $20.1 \pm 0.4$, macroseta on basitarsus IV $29.0 \pm 0.6$.

Male. Setae $\mathrm{r} 3$ and $\mathrm{R} 1$ on dorsal shield. Peritreme extending anteriorly to level of $\mathrm{z} 4$. Ventrianal shield fused with peritrematal shield, with 3 pairs of preanal setae; pair of crescentic solenostomes (Fig. 8). Fixed digit of chelicera with 4 teeth, the movable digit with a weak tooth; spermatodactyl with toe very narrow (Fig. 9). Measurements: length of idiosoma 217, width of idiosoma
114; lengths of setae $(n=10): j 117.3 \pm 0.5, j 322.1 \pm 0.3, j 4$ $17.1 \pm 0.2$, j5 $17.1 \pm 0.3, \mathrm{j} 615.4 \pm 0.4, \mathrm{~J} 2 \quad 15.0 \pm 0.2$, J5 4.4 $\pm 0.1, \mathrm{z} 222.0 \pm 0.3$, z4 $23.1 \pm 0.3$, z5 $16.7 \pm 0.3, \mathrm{Z} 116.6$ \pm 0.2 , Z4 16.8 \pm 0.1, Z5 $32.1 \pm 0.4$, s4 $29.4 \pm 0.2$, S2 19.5 \pm 0.3 , S4 16.4 \pm 0.2 , S5 $17.9 \pm 0.3, \mathrm{r} 321.8 \pm 0.3, \mathrm{R} 113.0$ \pm 0.2 , JV5 $18.4 \pm 0.4$, macroseta on basitarsus IV $26.4 \pm$ 0.2 .

Specimens examined. Lubuk Mintrum: 7우 \& 7ð, 7-XII-1981, on Bougainvillea sp.

Distribution. China; Indonesia (Sumatra), new record.

Remarks. The present female specimens generally agree with the descriptions based on Chinese materials of this species (Wu \& Li 1983; Wu et al. 1997), except for the slight difference in the reticulation of dorsal shield. In addition, ventral seta ST4 of Sumatran females is located on each metasternal platelet, whereas in Chinese specimens it was 
illustrated by $\mathrm{Wu}$ et al. (1997) to exist on the interscutal membrane but was described to be present on the platelet in their text.

The male of $A$. ( $N$.) circellatus, previously unknown, has been described. An Indian species, $A$. kalimpongensis Gupta 1969 might be a senior synonym of $A$. (A.) circellatus.

\section{Amblyseius (Neoseiulus) makuwa Ehara 1972}

(Fig. 10)

Amblyseius (Amblyseius) makuwa Ehara 1972, p. 154, figs. 7074 (type loc.: Kita-usa, Usa, Oita Pref., Kyushu; type habitat: Cucumis melo L. var. makuwa Makino); Ehara \& Hamaoka 1980, p. 6, fig. 8; Ryu 1993, p. 109, figs. 77-81; Ehara et al. 1994, p. 124.

Amblyseius makuwa: Chen et al. 1984, p. 335, fig. 14 (32); Wu et al. 1997, p. 99, fig. 69.

Amblyseius (Neoseiulus) makuwa: Ehara \& Amano 1998, p. 37.

A brown mite. The spermatheca of this species is distinctive in that the cervix is fundibular, very large and slender, and gradually narrows proximally to connect with the elliptical, basally incised atrium (Fig. 10). Leg IV is also distinctive in having 2 macrosetae on basitarsus and 1 macroseta on genu. Incidentally, genua I-III are deficient in macrosetae.

Specimen examined. Padang: 1 우, 2-XII-1981, on a leguminous weed.

Distribution. Japan (Honshu, Kyushu), Korea, China, Taiwan; Indonesia (Sumatra), new record.

\section{Amblyseius (Neoseiulus) okinawanus Ehara 1967}

(Figs. 11, 12)

Amblyseius (Amblyseius) okinawanus Ehara 1967, p. 72, figs. 17-24 (type loc.: Tomigusuku, Okinawa Island; type habitat: Verbena officinalis L.); Ehara \& Lee 1971, p. 64, fig. 8; Tseng 1976, p. 115, figs. 55-58; Ehara \& Hamaoka 1980, p. 6, figs. 9-11; Ryu \& Lee 1992, p. 27, figs. 22-30; Ehara et al. 1994, p. 124.

Amblyseius okinawanus: Chen et al. 1984, p. 342, fig. 14 (41); McMurtry \& Moraes 1985, p. 80; Wu et al. 1997, p. 89, fig. 59.

Amblyseius (Neoseiulus) okinawanus: Ehara \& Amano 1998, p. 37.

The measurements of setae $\mathrm{j} 1, \mathrm{j} 3, \mathrm{~s} 4, \mathrm{Z} 4$, and $\mathrm{Z} 5$ (means of 2 females; those of type series in parentheses) are 18 (21), 13 (16), 19 (22), 30 (35), and 76 (78), respectively. The spermathecal cervix is typically fundibular, and the atrium is incorporated into the base of the cervix (Figs. 11, 12). Genua II-IV bear 1 macroseta.

Specimens examined. Padang: 2ㅇ, 2-XII-1981, on a leguminous weed.

Distribution. Japan (Honshu, Kyushu, Amami-oshima I., Okinawa I.); Korea, China, Taiwan, Thailand; Indonesia (Sumatra), new record; Papua New Guinea, Russia.

\section{Amblyseius (Neoseiulus) asiaticus (Evans 1953)}

(Fig. 13)

Typhlodromus asiaticus Evans 1953, p. 461, figs. 7, 8 (type loc.: Java, Indonesia; no data about type habitat).

Typhlodromus (Amblyseius) asiaticus: Chant 1959, p. 80, figs. 140, 141.

Amblyseius (Amblyseius) asiaticus: Ehara 1966, p. 20; Ehara \& Bhandhufalck 1977, p. 58, figs. 50-55.

Amblyseius asiaticus: Schicha 1987, p. 94, pl. 4; Schicha \& Corpuz-Raros 1992, p. 60, pl. 45; Wu et al. 1997, p. 91, fig. 61.

Amblyseius linearis Corpuz \& Rimando 1966, p. 125, fig. 2 (type loc.: Gamu, Isabela, the Philippines; type habitat: Achyranthes aspera L.). Synonymy by Schicha \& CorpuzRaros (1992).

Amblyseius (Amblyseius) siaki Ehara \& Lee 1971, p. 64, figs. 912 (type loc.: Shek Kiu Tau, N. T., Hong Kong; type habitat: wild chrysanthemum). Synonymy by Ehara \& Bhandhufalck (1977).

The female of $A$. (N.) asiaticus is characterized by having seta R1 present on a lobe of dorsal shield. This distinctive character was described and figured by Ehara \& Bhandhufalck (1977). The spermathecal cervix is tubular, long and narrow, often coiled, and narrower than the atrium which is incorporated into the base of the cervix (Fig. 13). The posterior margin of the sternal shield is nearly straight. One macroseta is present on genua I-IV; those on I and II are often scarcely discernible.

Specimens examined. Padang: 2우, 1-XII-1981, on Stachytarpheta cayennensis (Rich.) J. Vahl; 2우, 1-XII-1981, on lantana; 8우 \& 30, 13-XII-1981, on a polygonaceous weed. Lubuk Mintrum: 10 우 \& 4ð, 7-XII-1981, on a leguminous weed; 3 우 \& 4ð, 7-XII-1981, on a melastomataceous plant. Ulu Gadut: 5우 \& 20, 7-XII-1981, on a leguminous weed.

Distribution. China, Thailand, Malaysia, Singapore, the Philippines; Indonesia (Java; Sumatra, new record); India, Cyprus (?), Angola (?).

\section{Amblyseius (Neoseiulus) newsami (Evans 1953)}

(Fig. 14)

Typhlodromus newsami Evans 1953, p. 450, figs. 1-4 (type loc.: Malaya; type habitat: rubber plant).

Typhlodromus (Amblyseius) newsami: Chant 1959, p. 96, figs. 220, 221.

Amblyseius (Amblyseius) newsami: Ehara 1966, p. 24.

Amblyseius newsami: Schicha 1982, p. 45, figs. 1-6; McMurtry

\& Moraes 1985, p. 79; Schicha 1987, p. 91, pl. 45.

Amblyseius (Neoseiulus) newsami: Ehara 2002, p. 30, fig. 2.

This species is closely allied to $A$. (N.) cantonensis Schicha 1982 originally described from China, but differs in that the spermathecal atrium (Fig. 14; Ehara 2002, fig. 2) is incorporated into the base of the cervix, not merely attached 

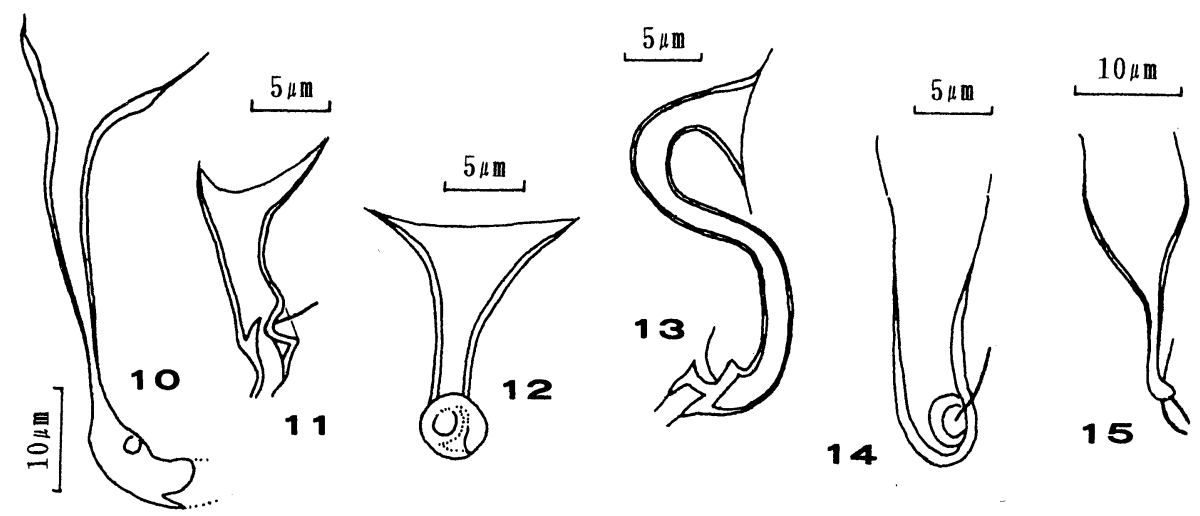

Figs. 10-15. Spermathecae. - 10, Amblyseius (Neoseiulus) makuwa; 11, 12, A. (N.) okinawanus; 13, A. (N.) asiaticus; 14, A. (N.) newsami; 15, Phytoseius (Dubininellus) rachelae.

to the base (Schicha 1982). Genua I-IV are provided with 1 macroseta.

A Chinese mite so far assigned to A. newsami (Ehara \& Lee 1971; Tseng 1983; Chen et al. 1984; Wu et al. 1997) should be referred to A. cantonensis (Schicha 1982, 1987; Ehara 2002). In addition, $A$. cantonensis from Thailand was also misidentified as $A$. newsami by Ehara \& Bhandhufalck (1977) (Ehara 2002).

Specimens examined. Padang: 29, 13-XII-1981, on Annona muricata $\mathrm{L}$.

Distribution. Malaysia; Indonesia (Sumatra), new record; Papua New Guinea.

\section{Amblyseius (Amblyseius) sumatrensis sp. nov.} (Figs. 16-27)

Female. Dorsal shield smooth, with 7 pairs of solenostomes (Fig. 16). Setae on dorsal shield: s4 very long, smooth; Z4 and Z5 very long, with minute barbs sparsely; $\mathrm{j} 1$ and $\mathrm{j} 3$ long, smooth; remaining setae much smaller, smooth. Setae $\mathrm{r} 3$ and R1 similar in length, smooth. Peritreme extending forward beyond seta $\mathrm{j} 1$; posterior extension of peritrematal shield with termination truncate (Figs. 17, 18). Sternal shield with posterior margin nearly straight, with 3 pairs of setae (Fig. 19). Ventrianal shield longer than wide, vase-shaped, narrower than genital shield, with anterior margin convex, the lateral margins concave; 3 pairs of preanal setae; pair of crescentic solenostomes just behind and very slightly inside JV2 (Fig. 20). Two pairs of slender metapodal platelets (Fig. 21). Spermathecal cervix tubular, slightly flaring distally; atrium incorporated into thick-walled proximal portion of cervix; distal portion of major duct with well-defined walls (Figs. 22, 23). Fixed digit of chelicera multidentate (11-12 teeth); movable digit with 4 teeth (Fig. 24). Chaetotaxic formula: genu II, 2-2/0, 2/0-1; genu III, 1-2/1, 2/0-1. Leg IV with 1 macroseta each on genu, tibia, and basitarsus (Fig. 25). Measurements: length of idiosoma 357 , width of idiosoma 259 , length of dorsal shield 333 , width of dorsal shield 246 ; lengths of setae (n=10): j1 35.2 \pm 0.4 (36.7), j3 45.3 \pm 0.8 (48.2), j4 7.8 \pm 0.2 (8.3), j5 6.2 \pm 0.2 (7.1), j6 9.0 \pm 0.5 (10.3), J2 10.6 \pm 0.3 (11.9), J5 $8.5 \pm 0.1$ (8.7), z2 $11.7 \pm 0.7$ (12.8), z4 10.5 \pm 0.4 (11.3), z5 7.8 \pm 0.5 (8.1), Z1 $12.2 \pm 0.3$ (11.7), Z4 $78.7 \pm 1.6$ (82.7), Z5 $251.3 \pm 2.2$ (254.9), s4 $79.7 \pm 1.4$ (84.3), S2 12.7 $\pm 0.2(12.8), \mathrm{S} 410.3 \pm 0.2(10.9), \mathrm{S} 59.3 \pm$ 0.3 (10.3), r3 10.7 \pm 0.3 (11.3), R1 $10.6 \pm 0.3$ (10.7), JV5 $53.0 \pm 1.0$ (58.5), macrosetae on leg IV: genu 111.4 \pm 2.2 (123.1), tibia 78.6 \pm 1.5 (84.7), basitarsus $59.5 \pm 0.8$ (60.0).

Male. Setae $\mathrm{r} 3$ and $\mathrm{R} 1$ on dorsal shield. Peritreme with anterior tip anterior to $\mathrm{j} 1$. Ventrianal shield fused with peritrematal shield, with 3 pairs of preanal setae and pair of crescentic solenostomes (Fig. 26). Dentition of chelicera not observable bacause of angle; spermatodactyl as figured (Fig. 27). Measurements: length of idiosoma 270, width of idiosoma 159; lengths of setae $(n=4)$ : j1 26.7, j3 36.8, j4 9.5, j5 8.5, j6 9.1, J2 10.8, J5 7.3, z2 10.7, z4 10.8, z5 7.5, Z1 11.3, Z4 56.8, Z5 180.9, s4 61.6, S2 12.1, S4 10.0, S5 9.0, r3 10.0, R1 11.3, JV5 27.1, macrosetae on leg IV: genu 68.4, tibia 51.3, basitarsus 46.3 .

Holotype. ㅇ (NSMT-Ac 11475), Lubuk Mintrum, 15-XII1981, on Lansium domesticum Corrêa.

Paratypes. Four slides (NSMT-Ac 11476-11479): Lubuk Mintrum: 2 우, with the same data as holotype ; 2 우 \& $10^{\lambda}, 2$-XII1981, on rambutan; 1ㅇ, 7-XII-1981, on papaya. Two slides (MZB): Lubuk Mintrum: 2 우 \& 20, 2 -XII-1981, on rambutan.

Other specimens. Four slides (private collection): Lubuk Mintrum: 1우 \& 1ð', 2-XII-1981, on rambutan; 1우, 3-XII-1981, on shaddock; 1ㅇ, 9-XII-1981, on durian; 2ㅇ, 15-XII-1981, on hibiscus.

Remarks. Amblyseius (A.) sumatrensis sp. nov. belongs to the A. largoensis species group (McMurtry \& Moraes 1984; Denmark \& Muma 1989). It is readily distinguished from other species in this group by the spermathecal atrium incorporated into the thick-walled proximal portion of the cervix. The relative lengths of main dorsal body setae are also useful in separating it from its congeners.

Etymology. This species is named after the Sumatra Island. 


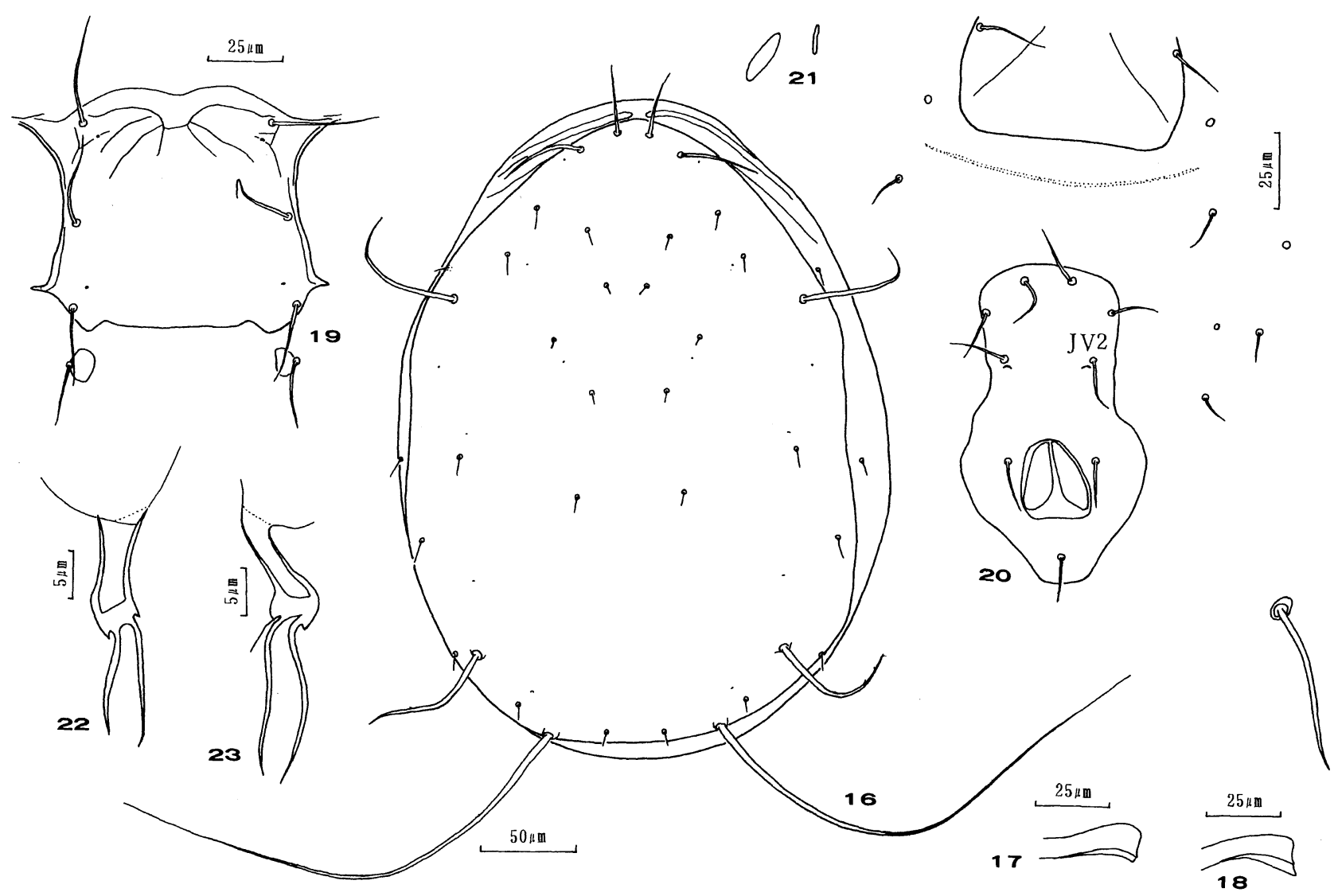

Figs. 16-23. Amblyseius (Amblyseius) sumatrensis sp. nov. - 16, dorsum of idiosoma ( $(+) ; 17,18$, caudal termination of

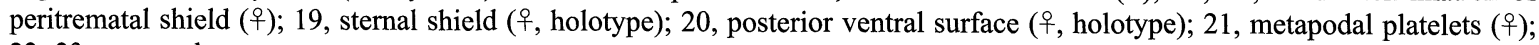
22, 23, spermatheca.

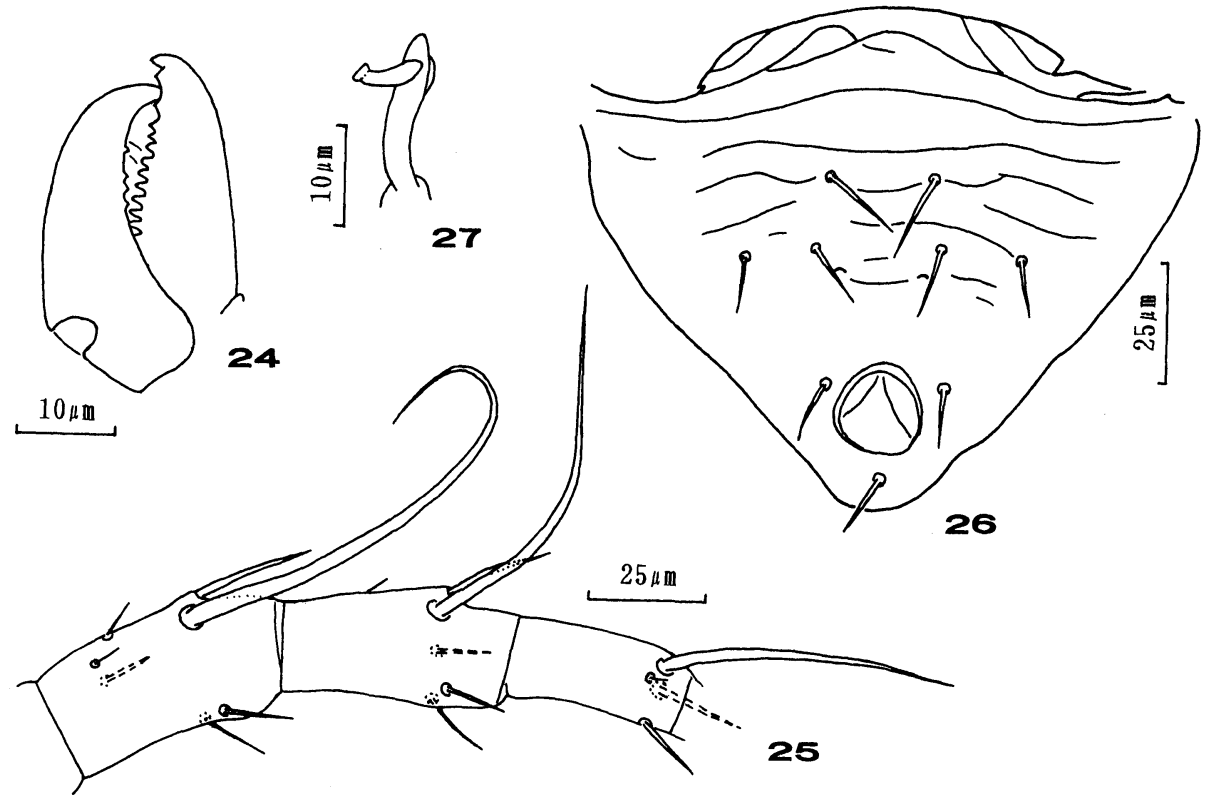

Figs. 24-27. Amblyseius (Amblyseius) sumatrensis sp. nov. — 24, chelicera (ㅇ); 25, genu, tibia, and basitarsus of leg IV (ㅇ, holotype); 26, ventrianal shield ( $\left.{ }^{7}\right) ; 27$, spermatodactyl. 


\section{Amblyseius (Euseius) ovalis (Evans 1953)}

Typhlodromus ovalis Evans 1953, p. 458, figs. 5, 6 (type loc.: Kuala Lumpur, Malaya; type habitat: rubber).

Amblyseius (Amblyseius) ovalis: Ehara 1967, p. 74, figs. 25-30; Ehara et al. 1994, p. 123.

Amblyseius ovalis: Schicha 1977, p. 127, figs. 28-34; Schicha 1987, p. 79, pl. 34; Schicha \& Corpuz-Raros 1992, p. 41, pl. 18.

Euseius ovalis: Gupta 1978, p. 335; Wu et al. 1997, p. 117, fig. 85.

Amblyseius (Euseius) ovalis: Ehara \& Amano 1998, p. 43, fig. 36.

The female of this species is characterized by the relative lengths of setae $\mathrm{j} 1, \mathrm{j} 3, \mathrm{~s} 4$ and $\mathrm{Z5}$, and the slender cervix of the spermatheca.

Specimens examined. Lubuk Mintrum: 2우 2-XII-1981, on rambutan; 1우, 3-XII-1981, on jackfruit.

Distribution. Japan (Okinawa I., Ishigaki I.), China, Taiwan, the Philippines, Malaysia; Indonesia (Sumatra), new record; India, Mauritius, Mexico, Hawaii, Fiji, Cook Islands, Papua New Guinea, Australia, New Zealand.

Paraphytoseius seychellensis Schicha \& Corpuz-Raros 1985 (Figs. 28-36)

Paraphytoseius seychellensis Schicha \& Corpuz-Raros 1985, p. 71, figs. 19-25 (type loc.: Casse-Dent-Mahe, Seychelles; type habitat: Asystasia coromandeliana Nees); Beard \& Walter 1996, p. 237, figs. 1-10.

Female. Dorsal shield smooth, with marginal notch near $\mathrm{s} 4$, with at least 5 pairs of solenostomes and 1 pair of notocephalic pores near $\mathrm{z} 5$ (Fig. 28). Thirteen pairs of setae on dorsal shield (S5 absent): j1, j3, s4, Z4 and Z5 long, thick, serrate, arising from tubercles; remaining setae much smaller, smooth. Setae r3 and R1 long, thick, serrate. Peritreme extending forward to base of $\mathrm{j} 1$. Sternal shield with posterior margin nearly straight, with 3 pairs of setae. Metasternal platelets longer than wide. Ventrianal shield slender, approximately pentagonal, much narrower than genital shield, the lateral margins slightly concave; 3 pairs of preanal setae and pair of minute pores (Fig. 29). Seta JV5 long, thick, serrate. A pair of very slender metapodal platelets. Spermathecal cervix disc-shaped, atrium nodular (Fig. 30). Fixed digit of chelicera with about 10 teeth; movable digit bidentate (Fig. 31). Chaetotaxic formula: genu II 2-2/0, $2 / 0-1$, genu III $1-2 / 1,2 / 0-1$. Genua I and III without macrosetae; genu II with 1 blunt-tipped macroseta. Leg IV with 1 knobbed, hyaline-tipped macroseta each on genu, tibia and basitarsus; telotarsus IV with 1 blunt-tipped macroseta (Fig. 32). Measurements: length of dorsal shield 289 , width of dorsal shield 156 ; lengths of setae $(n=4): j 1$ 32.4, j3 82.4, j4 5.5, j5 6.2, j6 8.7, J5 4.2, z2 14.3, z4 13.5, z5 6.6, Z1 7.5, Z4 67.3, Z5 103.6, s4 108.6, r3 43.8, R1 34.8 , JV5 79.7, macrosetae on legs: genu II 13.2, genu IV 21.9, tibia IV 27.6, basitarsus IV 35.0, telotarsus IV 39.5.

Male. Dorsal shield with notch on lateral margin near s4. Setae $\mathrm{r} 3$ and R1 on dorsal shield. Peritreme with anterior tip located at level of $\mathrm{j} 3$ to $\mathrm{j} 1$. Ventrianal shield not fused with peritrematal shield, carrying 3 pairs of preanal setae (Fig. 33 ). Fixed digit of chelicera with 2 subapical and 5-6 middle teeth; movable digit unidentate (Fig. 34); spermatodactyl with heel pointed (Figs. 35, 36). Measurements: length of dorsal shield 229, width of dorsal shield 130; lengths of setae $(n=10):$ j1 $23.0 \pm 0.3, j 353.2 \pm 0.8, j 44.7 \pm 0.2, j 55.2$ $\pm 0.2, \mathrm{j} 6 \quad 8.5 \pm 0.2, \mathrm{~J} 53.5 \pm 0.2, \mathrm{z} 2 \quad 12.1 \pm 0.2, \mathrm{z} 412.2 \pm$ $0.2, \mathrm{z} 55.5 \pm 0.2, \mathrm{Z} 16.6 \pm 0.2, \mathrm{Z} 443.6 \pm 0.5, \mathrm{Z} 552.1 \pm 1.0$,

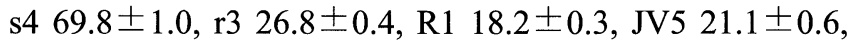
macrosetae on legs: genu II $11.5 \pm 0.1$, genu IV $18.2 \pm 0.3$, tibia IV $21.7 \pm 0.4$, basitarsus IV $29.7 \pm 0.4$, telotarsus IV $30.4 \pm 0.4$.

Specimens examined. Padang: 2 ㅇ \& $80^{\lambda}, 13-\mathrm{XII}-1981$, on a polygonaceous weed.

Distribution. Seychelles; Indonesia (Sumatra), new record; Australia.

Remarks. A detailed redescription of $P$. seychellensis is provided above. P. seychellensis is allied to $P$. multidentatus Swirski \& Shechter 1961 but differs in having leg IV without spatulate to knobbed non-macrosetae, as opposed to 4 (or 3) spatulate to knobbed non-macrosetae in $P$. multidentatus. Recently the latter was redescribed in detail (Ehara et al. 2000).

\section{Phytoseius (Phytoseius) hongkongensis Swirski \& Shechter 1961}

Phytoseius (Phytoseius) hongkongensis Swirski \& Shechter 1961, p. 99, figs. 1-5 (type loc.: Victoria Mt. forest, Hong Kong I.; type habitat: Heterosmilax gaudichaudiana A. DC.); Amitai \& Swirski 1966, p. 19, fig. 2; Denmark 1966, p. 44, fig. 17; Ehara \& Amano 1998, p. 50; Ehara 2002, p. 39.

Phytoseius (Pennaseius) hongkongensis: Ehara 1966, p. 25; Ehara \& Lee 1971, p. 70, figs. 32-37; Ehara 1972, p. 169, fig. 81; Ryu 1997, p. 131, figs. 7-15.

Phytoseius hongkongensis: Schicha 1984, p. 126; Schicha 1987, p. 162, pl. 118; Walter \& Beard 1997, p. 828.

Specimens examined: Padang: 2우, 13-XII-1981, on a polygonaceous weed.

Distribution. Japan (Kyushu, Taketomi I.), Cheju Island, China, Taiwan, Thailand, Malaysia; Indonesia (Sumatra), new record; Madagascar, Papua New Guinea, Australia.

\section{Phytoseius (Dubininellus) hawaiiensis Prasad 1968}

Phytoseius hawaiiensis Prasad 1968, p. 1460, figs. 7-11 (type loc.: Manoa, Oahu, Hawaii; type habitat: poinsettia); Schicha 1984, p. 123; Schicha 1987, p. 160, pl. 115; Corpuz-Raros \& Garcia 1994, p. 368, fig. 5; Walter \& Beard 1997, p. 836.

Phytoseius (Phytoseius) hawaiiensis: Ehara \& Bhandhufalck 1977, p. 48, figs. 14-21. 


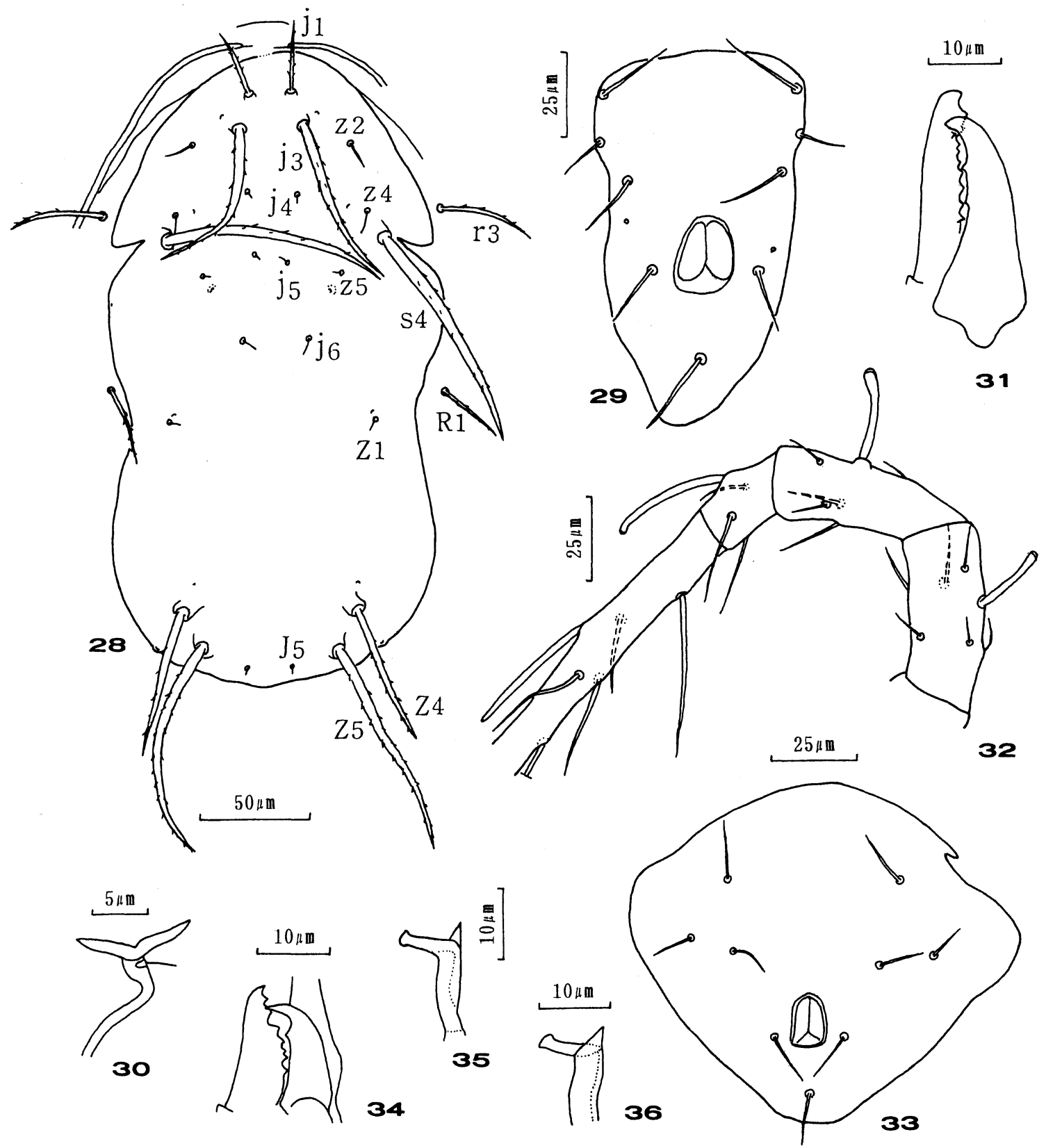

Figs. 28-36. Paraphytoseius seychellensis. - 28, dorsal shield ( + ); 29, ventrianal shield ( + ); 30 , spermatheca; 31 , chelicera ()); 32, tarsus, tibia, and genu of leg IV ( $(+)$; 33, ventrianal shield $\left({ }^{7}\right)$; 34, chelicera $\left({ }^{\Im}\right)$, with proximal part of spermatodactyl; 35,36 , spermatodactyl.

Phytoseius (Dubininellus) hawaiiensis: Ehara 2002, p. 40.

Specimens examined. Lubuk Mintrum: 1 우 \& 2ð⿱, $9-X I I-1981$, on grape.

Distribution. Japan (Ishigaki I., Taketomi I.); China, Hainan Island, Taiwan, Thailand, Malaysia, Singapore, the Philippines; Indonesia (Sumatra), new record; Mauritius, Papua New Guinea, Australia, Hawaii, Tahiti.
Phytoseius (Dubininellus) rachelae Swirski \& Shechter 1961

(Fig. 15)

Phytoseius (Dubininellus) rachelae Swirski \& Shechter 1961, p. 108, figs. 17-19 (type loc.: Sai Kung, New Territories, Hong Kong; type habitat: Rhus chinensis Mill.); Swirski \& Amitai 1966, p. 15, figs. 7-9; Amitai \& Swirski 1966, p. 21, fig. 6ac; Denmark 1966, p. 62, fig. 25; Gupta 1980, p. 52, fig. 1C. Phytoseius (Phytoseius) rachelae: Ehara \& Lee 1971, p. 72, figs. 
42-47; Gupta 1986, p. 253, figs. 609-613.

This species is characterized by the smooth dorsal shield, and by the relative lengths of its setae. The spermathecal cervix is fundubular, with basal duct very narrow, connecting with nodular atrium (Fig. 15).

Specimens examined. Padang: 2ㅇ, 1-XII-1981, on lantana.

Distribution. China; Indonesia (Sumatra), new record; India.

\section{Acknowledgments}

I am very grateful to Dr. A. Takafuji, Professor of Graduate School of Agriculture, Kyoto University, for offering the present valuable specimens taken by him. His survey on Sumatran mites was supported by a Grant-in-Aid for Overseas Scientific Survey from the Ministry of Education, Science and Culture, Japan (No. 56041027). My appreciation is also due to Dr. H. Amano (Chiba Univ.) and Mr. Sugeng Santoso (Kyoto Univ.) for their kind help during the course of this study.

\section{References}

Amitai, S. \& Swirski, E. 1966. Illustrations of spermathecae in several previously described phytoseiid mites (Acarina) from Hong Kong and Israel. Isr. J. Agr. Res., 16: 19-24.

Beard, J. J. 2001. A review of Australian Neoseiulus Hughes and Typhlodromips De Leon (Acari: Phytoseiidae: Amblyseiinae). Invert. Taxon., 15: 73-158.

Beard, J. J. \& Walter, D. E. 1996. Australian mites of the genera Paraphytoseius Swirski and Shechter and Paraamblyseius Muma (Acarina: Phytoseiidae). Aust. J. Entomol., 35: 235-241.

Chant, D. A. 1959. Phytoseiid mites (Acarina: Phytoseiidae). Can. Entomol., 91, Suppl., 12: 1-166.

Chen, S., Zhu, Z. \& Liang, L. 1984. Phytoseiid mites. pp. 306-363. In: Jiangxi Univ. (ed.) Zhongguo Nongye Man Lei [Agricultural Mites of China]. Shanghai Science \& Technology Press, Shanghai, 406 pp. (In Chinese)

Corpuz-Raros, L. A. \& Garcia, R. C.1994. New species records and new geographic and habitat records for some Philippine Phytoseiidae (Acari). Phil. Entomol., 9: 359-376.

Corpuz-Raros, L. A. \& Rimando, L. 1966. Some Philippine Amblyseiinae (Phytoseiidae: Acarina). Phil. Agr., 50: 114-136.

Denmark, H. A. 1966. Revision of the genus Phytoseius Ribaga, 1904 (Acarina: Phytoseiidae). Fla. Dept. Agr. Bull., 6: 1-105.

Denmark, H. A. \& Muma, M. H. 1989. A revision of the genus Amblyseius Berlese, 1914 (Acari: Phytoseiidae). Occas. Pap. Fla. State Coll. Arthropods, 4: i-iii+1-149.

Ehara, S. 1966. A tentative catalogue of predatory mites of Phytoseiidae known from Asia, with descriptions of five new species from Japan. Mushi, 39: 9-30.

Ehara, S. 1967. Phytoseiid mites from Okinawa Island (Acarina: Mesostigmata). Mushi, 40: 67-82.

Ehara, S. 1972. Some phytoseiid mites from Japan, with descriptions of thirteen new species (Acarina: Mesostigmata). Mushi, 46: 137173.

Ehara, S. 2002. Some phytoseiid mites (Arachnida: Acari: Phytoseiidae) from West Malaysia. Species Diversity, 7: 29-46.

Ehara, S. \& Amano, H. 1998. A revision of the mite family Phytoseiidae in Japan (Acari, Gamasina), with remarks on its biology. Species Diversity, 3: 25-73.

Ehara, S. \& Bhandhufalck, A. 1977. Phytoseiid mites of Thailand (Acarina: Mesostigmata). J. Fac. Educ. Tottori Univ. (Nat. Sci.), 27: 43-82.

Ehara, S., Gotoh, T. \& Amano, H. 2000. Two Japanese species of the genus Paraphytoseius Swirski and Shechter (Acari, Phytoseiidae).
J. Acarol. Soc. Jpn., 9: 113-118.

Ehara, S. \& Hamaoka, K. 1980. A new Typhlodromus from Japan with notes on four other species of phytoseiid mites. Acta Arachnol., 29: 3-8.

Ehara, S. \& Lee, L. H. Y. 1971. Mites associated with plants in Hong Kong. J. Fac. Educ. Tottori Univ. (Nat. Sci.), 22: 61-78.

Ehara, S., Okada, Y. \& Kato, H. 1994. Contribution to the knowledge of the mite family Phytoseiidae in Japan (Acari: Gamasina). J. Fac. Educ. Tottori Univ. (Nat. Sci.), 42: 119-160.

Evans, G. O. 1952. A new typhlodromid mite predaceous on Tetranychus bimaculatus Harvey in Indonesia. Ann. Mag. Nat. Hist., (12) 5: 413-416.

Evans, G. O. 1953. On some mites of the genus Typhlodromus Scheuten, 1857, from S. E. Asia. Ann. Mag. Nat. Hist., (12) 6: 449467.

Geijskes, D. C. 1939. Beiträge zur Kenntnis der europäischen Spinnmilben (Acari, Tetranychidae), mit besonderer Berücksichtigung der niederländischen Arten. Meded. Landbouwhogesch. Wageningen, 42 (4): 1-68.

Gupta, S. K. 1969. Three new species of the genus Amblyseius Berlese (Acarina: Phytoseiidae) from West Bengal, India. Bull. Entomol., 10: $126-129$.

Gupta, S. K. 1978. Some Phytoseiidae from South India with descriptions of five new species. Orient. Insects, 12: 327-338.

Gupta, S. K. 1980. New species and records of Phytoseius mites (Acarina: Mesostigmata) from South India. Bull. Zool. Surv. India, 3: $51-54$.

Gupta, S. K. 1986. Fauna of India. Acari: Mesostigmata. Family Phytoseiidae. ZSI, Calcutta, xvi+350+(v) pp.

McMurtry, J. A. \& Moraes, G. J. de 1984. Some phytoseiid mites from the South Pacific, with descriptions of new species and a definition of the Amblyseius largoensis species group. Internat. J. Acarol., 10: 27-37.

McMurtry, J. A. \& Moraes, G. J. de 1985. Some phytoseiid mites (Acari) of Papua New Guinea, with descriptions of six new species. Internat. J. Acarol., 11: 75-88.

Muma, M. H. 1955. Phytoseiidae (Acarina) associated with citrus in Florida. Ann. Entomol. Soc. Am., 48: 262-272.

Muma, M. H. 1967. New Phytoseiidae (Acarina: Mesostigmata) from southern Asia. Fla. Entomol., 50: 267-280.

Oomen, P. A. 1982. Studies on population dynamics of the scarlet mite, Brevipalpus phoenicis, a pest of tea in Indonesia. Meded. Landbouwhogesch. Wageningen, 82 (1): 1-88.

Oudemans, A. C. 1930. Acarologische Aanteekeningen CIII. Entomol. Ber., 8: 97-101.

Prasad, V. 1968. Some phytoseiid mites from Hawaii. Ann. Entomol. Soc. Am., 61: 1459-1462.

Rowell, H. J., Chant, D. A. \& Hansell, R. I. C. 1978. The determination of setal homologies and setal patterns on the dorsal shield in the family Phytoseiidae (Acarina: Mesostigmata). Can. Entomol., 110: 859-876.

Ryu, M. O. 1993. A review of the Phytoseiidae (Mesostigmata: Acarina) from Korea. Insecta Koreana, 10: 92-137.

Ryu, M. O. 1997. Four species of the phytoseiid mites from Cheju Island in Korea (Acari, Phytoseiidae). Kor. J. Appl. Entomol., 36: 129-133.

Ryu, M. O. \& Lee, W. K. 1992. Ten newly recorded phytoseiid mites (Acarina: Phytoseiidae) from Korea. Kor. J. Entomol., 22: 23-42.

Schicha, E. 1975. A new predacious species of Amblyseius Berlese from strawberry in Australia, and A. longispinosus (Evans) redescribed (Acari: Phytoseiidae). J. Aust. Entomol. Soc., 14: 101106.

Schicha, E. 1977. Amblyseius victoriensis (Womersley) and A. ovalis (Evans) compared with a new congener from Australia (Acari: Phytoseiidae). J. Aust. Entomol. Sci., 16: 123-133.

Schicha, E. 1982. A new species of Amblyseius from China compared with $A$. newsami (Evans) from Malaya (Acari: Phytoseiidae). Gen. 
Appl. Entomol., 14: 45-51.

Schicha, E. 1984. Contribution to the knowledge of the genus Phytoseius Ribaga in Australia, the South Pacific and Indian Ocean Regions with three new species and records of known species (Acarina: Phytoseiidae). Internat. J. Acarol., 10: 117-128.

Schicha, E. 1987. Phytoseiidae of Australia and Neighboring Areas. Indira Publishing House, Oak Park, Michigan, 187 pp.

Schicha, E. \& Corpuz-Raros, L. A. 1985. Contribution to the knowledge of the genus Paraphytoseius Swirski \& Shechter (Acarina: Phytoseiidae). Internat. J. Acarol., 11: 67-73.

Schicha, E. \& Corpuz-Raros, L. A. 1992. Phytoseiidae of the Philippines. Indira Publishing House, West Bloomfield, Michigan, 190 pp.

Swirski, E. \& Amitai, S. 1966. Descriptions of the males of four phytoseiid mites (Acarina) from Hong Kong. Isr. J. Agr. Res., 16: 11-18.

Swirski, E. \& Shechter, R. 1961. Some phytoseiid mites (Acarina: Phytoseiidae) of Hong Kong, with a description of a new genus and seven new species. Isr. J. Agr. Res., 11: 97-117.

Tseng, Y. H. 1976. Systematics of the mite family Phytoseiidae from Taiwan, with a revised key to genera of the world (II). J. Agr. Assoc. China, New Ser., 94: 85-128.

Tseng, Y. H. 1983. Further study on phytoseiid mites from Taiwan (Acarina: Mesostigmata). Chin. J. Entomol., 3: 33-74.

Walter, D. E. \& Beard, J. J. 1997. A review of the Australian Phytoseiinae (Acari: Mesostigmata: Phytoseiidae). Invert. Taxon., 11: 823-860.

Wu, W. N. \& Li, Z. 1983. Descriptions of four new species of phytoseiid mites and the male of Iphiseius dinghuensis from Fujian Province (Acarina: Phytoseiidae). Wuyi Sci. J., 3: 170-176. (In Chinese with English summary)

Wu, W. N., Liang, L. \& Lan, W. 1997. Acari: Phytoseiidae. Economic Insect Fauna of China. Fasc. 53. Science Press, Beijing, viii +223 pp., 3 pls. (In Chinese)

Received August 9, 2002 / Accepted September 20, 2002 
従来ヒメアシダカグモに使用されていた Sinopoda stellata （Schenkel 1963）を日本のクモから削除した．同種は中国内陸 部に固有の種と考えられる。

スマトラ島のカブリダニ類（ダニ目：カブリダニ科）（pp. 125133

江原昭三（勇680-0001 鳥取市浜坂 2丁目 15-7）（pp. 125-133）

高藤晃雄氏（京都大学）が 1981 年 12 月にインドネシアのス マトラ島で種々の植物から採集した標本が，この研究に用いら れた. 12 種のカブリダニが同定され，この中の 1 種は新種で, Amblyseius (A.) sumatrensis として記載された。他の 11 種はす べてスマトラからの新記録種である。これらのうち, 従来あま りょく知られていない Amblyseius (Neoseiulus) circellatus Wu \& Li 1983, および Paraphytoseius seychellensis Schicha \& CorpuzRaros 1985 については, 再記載が与えられた。前者の雄はこの たび初めて記載された，残りの種の大部分については，主要な 識別形質が記述された.

中国地方産のモリヒメグモ属（クモ目：ヒメグモ科）の 3 種 (pp. 135-137)

吉田 哉 (下990-2484 山形市篭田 2丁目 7 番 16 号)

中国地方からモリヒメグモ属 Robertus の 3 種を記録した。 そのうちの 1 種, ノジマモリヒメグモ（新称） R. nojimai, を 新種として記載した。その他の 2 種, キタモリヒメグモ $R$. sibiricus Eskov 1987 抢よびサイトウモリヒメグモ R. saitoi Yoshida 1995，を岡山県および鳥取県から初めて記録した。 キ タモリヒメグモは本州新記録となる。
長野県産のタカユヒメグモ属（クモ目：ヒメグモ科）の 1 新種 (pp. 139-140)

吉田 哉（广990-2484 山形市篭田 2丁目 7 番 16 号）

長野県産のヒメグモ科タカユヒメグモ属 Takayus の 1 新種を フジサワヒメグモ（新称）T. fujisawai の名前で記載した. 高 山村山田牧場の上部標高 $1,750 \mathrm{~m}$ ほどの尾根部分で, ウラジロ モミ（ダケモミ）Abies homolepis Sieb. \& Zucc.に網を張ってい るところを採集された。

南西諸島産のユウレイグモ属およびシモングモ属（クモ目，ユ ウレイグモ科) の 2 新種 (pp. 141-144)

入江照雄（下860-0082 熊本市池田 2 丁目 19-11）

南西諸島産のユウレイグモ科の 2 新種, Pholcus okinawaensis オキナワユウレイグモ(新称, 沖縄島産, 与論島産)打よび Spermophora yanbaruensis ヤンバルユウレイグモ（新称, 沖縄 島産）を記載した。

日本初記録のソルホイオニダニ（ササラダニ亜目 : オニダニ科） (pp. 145-147)

島野智之 ${ }^{1}$, 坂田知世 ${ }^{2}$, Roy A. Norton ${ }^{2}$ ('T960-2156 福島市荒 井字原宿南 50 東北農業研究センター烟地利用部 畑土壌管 理研究室; ${ }^{2}$ College of Environmental Science and Forestry, State University of New York, USA)

Camisia solhoeyi Colloff（ソルホイオニダニ, 新称）を初めて 日本から記録した，本種は，胴背毛 $\mathrm{h} 1$ が他の胴背毛よりあ短 いという特徴によって日本に生息する他の近縁な種と区別でき る. よく知られている C. lapponica (Trägårdh) は, 本種と非常 によく似て抢り, 以前の C. lapponica の日本での記録は, 再調 查される必要があるかも知れない. 